\title{
ROTIFER PRODUCTION IN A SHALLOW ARTIFICIAL LAKE (LOBO-BROA RESERVOIR, SP, BRAZIL)
}

\author{
PELÁEZ-RODRÍGUEZ, M. and MATSUMURA-TUNDISI, T. \\ International Institute of Ecology São Carlos, Rua Bento Carlos, 750, CEP 13560-660, São Carlos, SP, Brazil \\ Correspondence to: Marlon Peláez-Rodrígues, International Institute of Ecology São Carlos, \\ Rua Bento Carlos, 750, CEP 13560-660, São Carlos, SP, Brazil, e-mail: mapelaez@bol.com.br; tmt.iie@iie.com.br \\ Received May 3, 2001 - Accepted Dezember 11, 2001 - Distributed August 31, 2002
}

(With 3 figures)

\begin{abstract}
Rotifer production in a shallow artificial lake (Lobo-Broa Reservoir) was studied for twenty consecutive days between August 25, 1995 and September 13, 1995, during the dry season. Two species were dominant, during this period namely Filinia pejleri and Keratella americana, contributing, respectively, $36 \%$ and $28 \%$ to total rotifer numbers. Production estimates of these species were, respectively, 41.93 and $80.70 \mu \mathrm{g}$ dry weight. $\mathrm{m}^{-3} \cdot \mathrm{d}^{-1}$, corresponding to 18.45 and $35.51 \mu \mathrm{gCm}{ }^{-3} \cdot \mathrm{d}^{-1}$. The population of $F$. pejleri was numerically more abundant than that of $K$. americana, while the production of the former was less, as a result of lower egg to female ratios.
\end{abstract}

Key words: Rotifer, production, reservoir.

\section{RESUMO}

\section{Produção de populações de Rotifera em um pequeno lago artificial} (Reservatório do Lobo-Broa, SP, Brasil)

A produção de rotíferos da Represa do Lobo-Broa foi estudada durante o período de vinte dias consecutivos, no inverno (25/8/95 a 13/9/95). Amostragens diárias foram efetuadas com a finalidade de conhecer a influência das condições físicas e químicas do ambiente na dinâmica das populações de Rotifera em um curto intervalo de tempo. Duas espécies dominaram nesse período: Filinia pejleri e Keratella americana, as quais contribuíram com $36 \%$ e $28 \%$, respectivamente, do total da densidade de Rotifera. A produção secundária dessas espécies foi calculada em 41,93 $\mu \mathrm{gPeso}-\mathrm{Seco} \cdot \mathrm{m}^{-3} \cdot \mathrm{d}^{-1} \mathrm{e}$ $80,70 \mu \mathrm{gPeso}-$ Seco. $\mathrm{m}^{-3} \cdot \mathrm{d}^{-1}$, correspondendo a $18,45 \mathrm{e} 35,51 \mu \mathrm{gCm}^{-3} \cdot \mathrm{d}^{-1}$, respectivamente. A população de $F$. pejleri foi mais abundante que a população de $K$. americana, porém, sua produção foi menor, devido a sua baixa razão ovo/fêmea.

Palavras-chave: Rotifera, produção, reservatório.

\section{INTRODUCTION}

Lobo-Broa Reservoir is a shallow, turbulent reservoir located in the center of São Paulo State (Fig. 1). It was constructed in 1936, initially for hydroelectric power supply. Today, besides being used for scientific experimental and applied research, Lobo-Broa Reservoir is used for recreation and sport fisheries. Limnological studies that have been carried out since 1971 show that it is a reasonably preserved environment from the human activities presenting low concentration of nutrients (nitrate $6.50 \mu \mathrm{g} . \mathrm{L}^{-1}$, ammonium 23.10 $\mu \mathrm{g} . \mathrm{L}^{-1}$ and orthophosphate $7.0 \mu \mathrm{g} . \mathrm{L}^{-1}$ ); low chlorophyll $a\left(4.5 \mu \mathrm{g} . \mathrm{L}^{-1}\right)$ and a well-oxygenated water column (7.6 mg. $\left.\mathrm{L}^{-1}\right)$ (Rodríguez \& Matsumura-Tundisi, 2000).

Trophic relationships studies were carried out by Tavares \& Matsumura-Tundisi (1984) and Matsumura-Tundisi \& Tavares (1986) involving experiments on feeding rates on phytoplankton by the copepod Argyrodiaptomus furcatus; the secondary production of this species was determined by Rocha \& Matsumura-Tundisi (1984). 


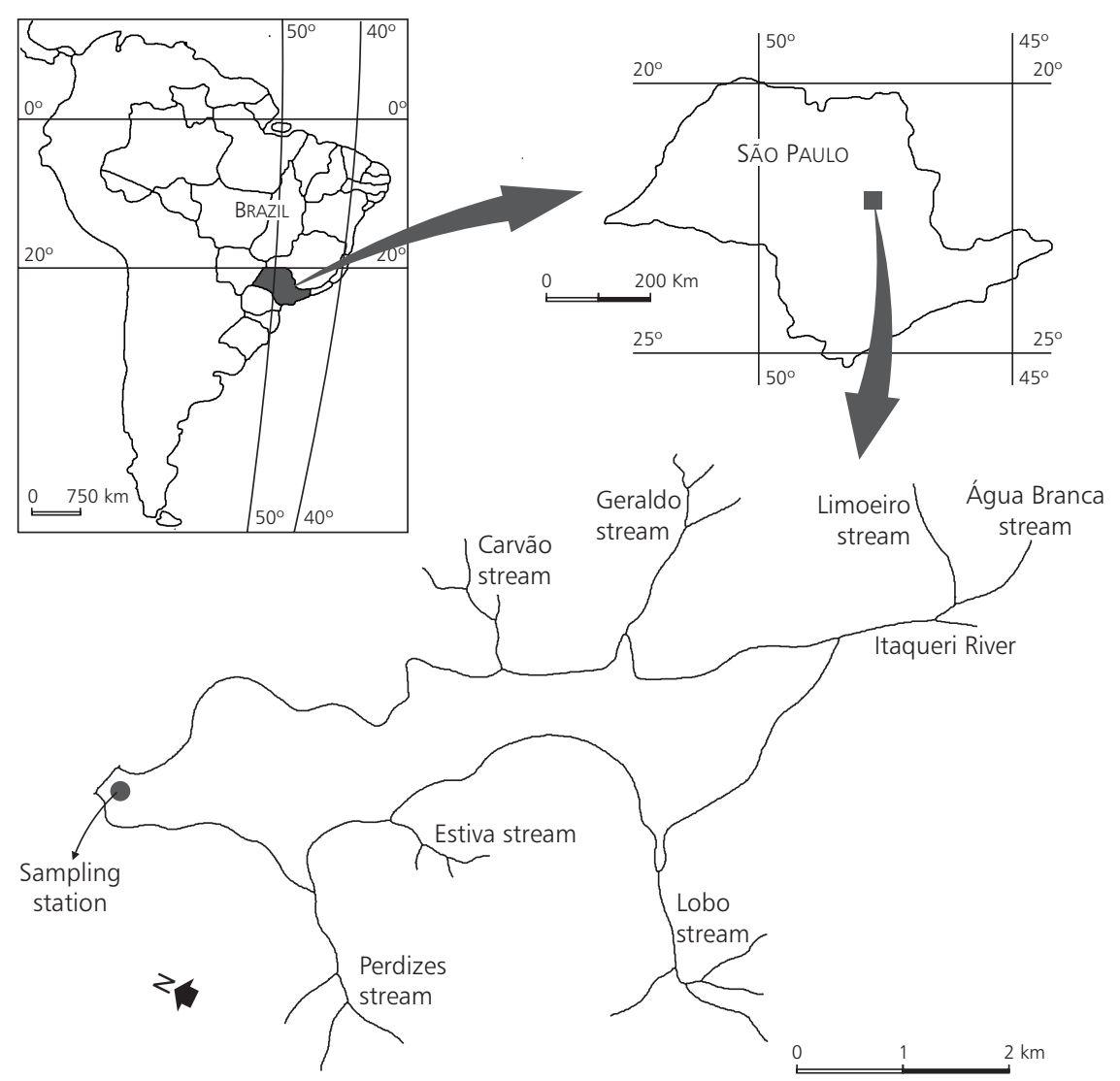

Fig. 1 - Map of Lobo-Broa Reservoir showing its location in São Paulo State and Brazil. Sampling station is also shown.

Of the zooplankton community of this reservoir, the Rotifera contribute about $80 \%$ of total abundance (Matsumura-Tundisi \& Tundisi, 1976).

Rotifers are considered opportunistic organisms, showing high adaptive capacity, colonizing rapidly a wide variety of habitats and niches. They can constitute an important link in the food chain between the primary producers and secondary consumers, such as fish larvae and benthos (Nogrady et al., 1993). The role of the rotifers in energy flow is of great importance due to their high reproductive potential associated with their relatively short life cycles, implying an important conversion of organic matter via production (Winberg, 1971; Elser et al., 1988). The rotifers also participate in recycling of nutrients, and, thereby, in freshwater ecosystem productivity. According to Makarewicz \& Likens (1979), of the phosphorous annually incorporated by the zooplankton in Mirror Lake (USA), the rotifers were responsible for about one third.
Secondary production can be defined as the increase in biomass, including reproductive products, within a unit of time. According to Downing (1984), secondary production studies are important in elucidating the transfer of energy and material within the ecosystem, permitting the more rational management of aquatic resources.

Various works have been published with the aim of revising and systematizing concepts and techniques concerning the secondary production of zooplankton organisms (Winberg et al., 1971; Edmondson, 1974; Bottrell et al., 1976; Downing $\&$ Rigler, 1984).

Estimates of rotifer production are generally carried out based on analyses of values for the finite birth rate and organism dry weight using the recruitment method, according to Elster (1954, 1955) or the method of Galkovskaya (1965) based on generation time (in Edmondson \& Winberg, 1971). 
The present work aimed in analysing secondary production of Rotifera of Lobo-Broa reservoir using the recruitment method, which is applied principally to organisms, which show slight (almost imperceptible) differences in size between new-born and adult individuals, and involves the direct measurement of the number of organisms and growth rates (Infante, 1988). Such information should provide insights into the productive potential of these organisms, as well as their functional role in the ecosystem.

\section{MATERIAL AND METHODS}

Daily samples were carried out at the fixed station of Lobo-Broa Reservoir, near the dam, at the deepest region, which is $10 \mathrm{~m}$ deep, during the period of August 25 to September 13, 1995. The morphometry and the general characteristics of the reservoir are described in Tundisi et al. (1972 a, b).

Zooplankton samples were obtained using net plankton with $40 \mu \mathrm{m}$ mesh size through the vertical hauls lowering the net to the bottom twice and obtaining approximately $1.3 \mathrm{~m}^{3}$ of filtered water. The concentrated material was fixed with $4 \%$ formaldehyde.

The production of the dominant species of Rotifera during this period (F. pejleri and K. americana) was calculated using the recruitment method, according to Elster (in Edmondson \& Winberg, 1971) based on the values for the finite birth rate and organism dry weight.

$$
P=P_{N} \cdot W
$$

where:

$P \quad=$ production in dry weight of organic matter

$P_{N}=$ recruitment of new individuals

$W=$ mean individual body dry weight

$$
P_{N}=N_{f} . B
$$

where:

$N_{f}=$ number of females

$B=$ finite birth rate

$$
B=\frac{E}{D e} \quad \text { (Edmondson, 1960) }
$$

where:

$E=$ proportion of eggs/female

$D e=$ egg development time
De was calculated using the formula of Bottrell et al. (1976):

$$
\ln D e=\ln a+b \cdot \ln t+c \cdot(\ln t)^{2}
$$

where:

$\ln a=2.7547 ; b=-0.2484 ; c=-0.2408 ;$

$t=$ temperature $\left({ }^{\circ} \mathrm{C}\right)$

\section{Dry weight (W)}

Rotifer dry weight was estimated using an indirect technique of bio volume calculation from body size measurements and application of approximate geometric formulae (Ruttner-Kolisko, 1977).

\section{RESULTS}

The production of rotifers of Lobo-Broa Reservoir in the period of August to September 1995 was estimated considering the two most abundant species that occurred in this period: Filinia pejleri and Keratella americana that performed $64 \%$ of rotifer populations (Rodríguez \& Matsumura-Tundisi, 2000).

Table 1 shows the temperature, n. of females and n. of eggs for the populations of Filinia pejleri and Keratella americana. The egg development time $(D e)$, finite birth rate $(B)$, recruitment of new individuals $\left(P_{N}\right)$, necessary parameters to obtain the production $(P)$ are presented in the Table 2 . The data show that at temperatures between $20.4^{\circ} \mathrm{C}$ and $22.2^{\circ} \mathrm{C}$, egg development time varied between 0.72 and 0.83 days, with a mean value of 0.8 days, which is equivalent to 19 hours and 13 minutes.

The bio volume technique used to calculate the dry weight of the two species considered is presented in the Table 3.

The geometric formula used for F. pejleri was an ellipsoid of revolution, with appendices (setae) representing $9 \%$ of the body volume, while the formula used for $K$. americana was a half cone. The body dimensions measured (in $\mu \mathrm{m}$ ), the calculated bio volume (in $\mu \mathrm{m}^{3}$ ), the conversion factor for transforming wet weight to dry weight, and the dry weight biomass (in $\mu \mathrm{gDW}$ ). The calculated volume was converted to wet and then dry weight, using, for F. pejleri and $K$. americana, respectively, the estimates of dry to wet weight of $11 \%$ and $26 \%$ for Filinia terminalis and Keratella cochlearis, respectively, according to Pauli (1989). 
TABLE 1

Data of temperature, n. of females.m ${ }^{-3}\left(N_{f}\right)$, n. of eggs.m ${ }^{-3}$ for Filinia pejleri and Keratella americana obtained in the period of August 25 to September 13, 1995.

\begin{tabular}{|c|c|c|c|c|c|}
\hline \multirow{2}{*}{$\begin{array}{l}\text { Data } \\
1995\end{array}$} & \multirow{2}{*}{ Temperature ${ }^{\circ} \mathrm{C}$} & \multicolumn{2}{|c|}{ Number of females. $\mathrm{m}^{-3}\left(N_{f}\right)$} & \multicolumn{2}{|c|}{ Number of eggs.m ${ }^{-3}$} \\
\hline & & F. pejleri & K. americana & F. pejleri & K. americana \\
\hline August, 25 & 20.7 & 2462 & 9615 & 222 & 2115 \\
\hline 26 & 20.7 & 4615 & 17308 & 92 & 4846 \\
\hline 27 & 20.5 & 1000 & 7846 & 0 & 2275 \\
\hline 28 & 20.7 & 1231 & 5846 & 234 & 2163 \\
\hline 29 & 21.0 & 2308 & 5000 & 531 & 1400 \\
\hline 30 & 20.9 & 4692 & 3231 & 235 & 1066 \\
\hline 31 & 21.5 & 11308 & 6692 & 2035 & 1673 \\
\hline September, 1 & 21.5 & 11769 & 6462 & 1412 & 1551 \\
\hline 2 & 21.3 & 8462 & 8385 & 423 & 1174 \\
\hline 3 & 22.2 & 21385 & 5462 & 2780 & 819 \\
\hline 4 & 20.9 & 17154 & 12154 & 1544 & 2309 \\
\hline 5 & 20.8 & 20385 & 20538 & 2242 & 4929 \\
\hline 6 & 20.6 & 19000 & 17692 & 2090 & 2477 \\
\hline 7 & 20.6 & 45692 & 15923 & 5026 & 2548 \\
\hline 8 & 20.4 & 39615 & 26923 & 1188 & 4308 \\
\hline 9 & 20.6 & 35692 & 31846 & 4283 & 7006 \\
\hline 10 & 20.5 & 43462 & 33154 & 3477 & 5968 \\
\hline 11 & 20.6 & 29769 & 25692 & 1786 & 5395 \\
\hline 12 & 21.1 & 34692 & 47846 & 694 & 7655 \\
\hline 13 & 20.4 & 85077 & 29769 & 3403 & 3572 \\
\hline Mean values & 20.9 & 21988 & 16869 & 1979 & 3711 \\
\hline
\end{tabular}

For F. pejleri, mean body length was 121 $\mu \mathrm{m}$, and mean body width was $54 \mu \mathrm{m}$, giving a biovolume of 203,035 $\mu \mathrm{m}^{3}$. Applying the wet weight - dry weight conversion factor of $11 \%$ gave a dry weight of $0.02 \mu$ gind $^{-1}$.

For K. americana, mean body length was 193 $\mu \mathrm{m}$, and mean body width was $55 \mu \mathrm{m}$, providing a bio volume of $79,228 \mu \mathrm{m}^{3}$. Applying the wet weight - dry weight conversion factor of $26 \%$ gave a dry weight of $0.02 \mu$ gind $^{-1}$.

\section{Relation between temperature and egg development time}

Fig. 2 shows the relation between the water temperature and egg development time for both species considered. 
TABLE 2

Data of $D e, B, P_{N}$ and $P\left(\mathrm{mgDW} \cdot \mathrm{m}^{-3} \cdot \mathrm{d}^{-1}\right)$ for two species of rotifers.

\begin{tabular}{|c|c|c|c|c|c|c|c|}
\hline \multirow{2}{*}{$\begin{array}{l}\text { Data } \\
1995\end{array}$} & \multirow{2}{*}{$D e$} & \multicolumn{2}{|r|}{$\boldsymbol{B}$} & \multicolumn{2}{|r|}{$\boldsymbol{P}_{N}$} & \multicolumn{2}{|r|}{$P$} \\
\hline & & F. pejleri & K. americana & F. pejleri & K. americana & F.pejleri & K. americana \\
\hline August, 25 & 0.81 & 0.12 & 0.28 & 295 & 2692 & 5.91 & 53.84 \\
\hline 26 & 0.81 & 0.02 & 0.34 & 92 & 5885 & 1.85 & 117.69 \\
\hline 27 & 0.83 & 0.00 & 0.36 & 0 & 2825 & 0.00 & 56.49 \\
\hline 28 & 0.81 & 0.23 & 0.45 & 283 & 2631 & 5.66 & 52.61 \\
\hline 29 & 0.79 & 0.29 & 0.35 & 669 & 1750 & 13.39 & 35.00 \\
\hline 30 & 0.80 & 0.06 & 0.42 & 282 & 1357 & 5.63 & 27.14 \\
\hline 31 & 0.76 & 0.24 & 0.33 & 2714 & 2208 & 54.28 & 44.17 \\
\hline September, 1 & 0.76 & 0.16 & 0.31 & 1883 & 2003 & 37.66 & 40.06 \\
\hline 2 & 0.77 & 0.06 & 0.18 & 508 & 1509 & 10.15 & 30.19 \\
\hline 3 & 0.72 & 0.18 & 0.22 & 3849 & 1202 & 76.99 & 24.03 \\
\hline 4 & 0.80 & 0.11 & 0.24 & 1887 & 2917 & 37.74 & 58.34 \\
\hline 5 & 0.81 & 0.14 & 0.30 & 2854 & 6161 & 57.08 & 123.23 \\
\hline 6 & 0.82 & 0.13 & 0.17 & 2470 & 3008 & 49.40 & 60.15 \\
\hline 7 & 0.82 & 0.13 & 0.20 & 5940 & 3185 & 118.80 & 63.69 \\
\hline 8 & 0.83 & 0.03 & 0.19 & 1188 & 5115 & 23.77 & 102.31 \\
\hline 9 & 0.82 & 0.14 & 0.27 & 4997 & 8598 & 99.94 & 171.97 \\
\hline 10 & 0.83 & 0.10 & 0.22 & 4346 & 7294 & 86.92 & 145.88 \\
\hline 11 & 0.82 & 0.08 & 0.26 & 2382 & 6680 & 47.63 & 133.60 \\
\hline 12 & 0.78 & 0.03 & 0.20 & 1041 & 9569 & 20.82 & 191.38 \\
\hline 13 & 0.83 & 0.05 & 0.14 & 4254 & 4168 & 85.08 & 83.35 \\
\hline Average & 0.80 & 0.11 & 0.27 & 2419 & 4555 & 48.37 & 91.09 \\
\hline
\end{tabular}

There is a relationship between temperature and egg development time for both species.

At lower temperatures $\left(20.5^{\circ} \mathrm{C}\right)$ the egg development time takes approximately 21 hours while at more high temperatures $\left(22.5^{\circ} \mathrm{C}\right)$ it takes 17 hours. The productions calculated for both populations of rotifers and their daily fluctuations can be observed in the Fig. 3. The average value of production of Filinia pejleri obtained during the consecutive twenty days (August 25 to September 13, 1995) analysed it was $41.93 \mu \mathrm{gDWm}{ }^{-3} \cdot \mathrm{d}^{-1}$ with a maximum value of $118.80 \mu \mathrm{gDWm}^{-3} \cdot \mathrm{d}^{-1}$ while for Keratella americana the average value was $80.70 \mu \mathrm{gDWm}^{-3} \cdot \mathrm{d}^{-1}$ with a maximum values of $191.38 \mu \mathrm{gDWm}^{-3} \cdot \mathrm{d}^{-1}$

The production of $F$. pejleri was low during the first few days of the study, with a tendency to increase, although in an irregular pattern. The production of $K$. americana was relatively high at the beginning of the study period, also tending to increase during the second half of the study. Production of the latter species was generally greater than that of the former. 
TABLE 3

Geometric formulae used for the calculation of the body volume, the body dimensions measured (in $\mu \mathrm{m}$ ), the calculated biovolume (in $\mu^{3}$ ), the conversion factor for transforming wet weight to dry weight, and the dry weight biomass (in $\mu \mathrm{gDW}$ ), for Filinia pejleri and Keratella americana.

\begin{tabular}{|c|c|c|c|c|c|c|c|c|}
\hline Species & $\begin{array}{c}\text { Geometric } \\
\text { formula } \\
\text { used }\end{array}$ & $\begin{array}{l}\text { Measureme } \\
\text { nt used for } \\
\text { formula }\end{array}$ & $\begin{array}{c}\text { Dimensions } \\
\qquad(\mu \mathrm{m})\end{array}$ & $\begin{array}{c}\text { Appendices } \\
\text { in \% of body } \\
\text { volume }\end{array}$ & $\begin{array}{l}\text { Biovolume } \\
\qquad\left(\mu \mathbf{m}^{3}\right)\end{array}$ & $\begin{array}{l}\text { Factor } \\
\text { (wet:dry) }\end{array}$ & $\begin{array}{c}\text { Biomass } \\
\left(\mu \mathrm{gDWm}^{-3} \text { ind }^{-1}\right)\end{array}$ & $\begin{array}{c}\text { Body: } \\
\mathbf{a}=\text { length } \\
\mathbf{b}=\text { width } \\
\mathrm{c}=\text { height }\end{array}$ \\
\hline $\begin{array}{l}\text { Filinia } \\
\text { pejleri }\end{array}$ & $\begin{array}{c}\begin{array}{c}\text { Ellipsoid of } \\
\text { revolution }\end{array} \\
\frac{4 . \pi \cdot r_{1} \cdot r_{2} \cdot r_{3}}{3}\end{array}$ & $\begin{array}{c}\mathrm{a}=2 \mathrm{r}_{3} \\
\mathrm{~b}=2 \mathrm{r}_{1} \\
\mathrm{c}=2 \mathrm{r}_{2} \\
\mathrm{~b}=\mathrm{c}\end{array}$ & $\begin{array}{c}\mathrm{a}=121 \\
\mathrm{~b}=\mathrm{c}=54\end{array}$ & $16,767=9 \%$ & $\begin{array}{c}203,035 \\
\left(\mu \mathrm{m}^{3}\right)\end{array}$ & $11 \%$ & 0.02 & \\
\hline $\begin{array}{l}\text { Keratella } \\
\text { americana }\end{array}$ & $\begin{array}{l}1 / 2 \text { cone } \\
\frac{\pi \cdot r^{2} \cdot h}{6}\end{array}$ & $\begin{array}{l}\mathrm{a}=\mathrm{h} \\
\mathrm{b}=2 \mathrm{r}\end{array}$ & $\begin{array}{c}\mathrm{a}=193 \\
\mathrm{~b}=55\end{array}$ & - & $\begin{array}{c}79,228 \\
\left(\mu \mathrm{m}^{3}\right)\end{array}$ & $26 \%$ & 0.02 & $\mathrm{~b}$ 这 \\
\hline
\end{tabular}

\section{DISCUSSION}

Studies carried out in reservoirs have indicated that one of the principal characteristics of such systems is the dominance of rotifers over other groups of zooplankton, when population density is considered. In terms of biomass, whether in dry weight or carbon content, the situation differs (Matsumura-Tundisi \& Tundisi, 1986; Matsumura-Tundisi et al., 1989), with the rotifers tending to become the group of least importance, and the Copepoda of most importance. Analysis of biomass gives estimates of the energy stored as organic matter by the population, and, if done for each trophic level, can assist the estimation of energy fluxes within the community and the productive potential of the system. However, the biomass of organisms present at any particular time does not necessarily reflect the rate of production of new matter or the rate of energy processing. Thus, among the zooplankton, the Rotifera can contribute less biomass when compared to such groups as the Cladocera and Copepoda, but have higher turnover times. Thus, when considering functional processes, the analysis of production offers a measurement, which is more realistic concerning the contribution in energetic and resource terms of each of the components of the community. Egg development time is directly related to temperature, with a value for rotifers in the tropics of about 20 hours. Okano (1994) obtained for the species Brachionus falcatus, F. longiseta and $K$. cochlearis in the reservoir of Monjolinho (SP), where mean water temperature was $20.4^{\circ} \mathrm{C}$, an egg development time of approximately 0.83 day (20 hours). The egg development time for $F$. pejleri and $K$. americana in the present study, where mean water temperature was approximately $20.9^{\circ} \mathrm{C}$, was calculated to be approximately 19 hours. The species from temperate region studied by Edmondson (1960) presented development times of 42 to 43 hours.

Despite the fact that the population of $F$. pejleri was numerically more abundant than that of $K$. americana, the former production was lower as a result of its lower egg ratio. The population size of $K$. americana was also affected by having a higher mortality rate than that of $F$. pejleri.

The Lobo-Broa Reservoir has been considered a nutrient-poor system with low concentrations of Nitrogen and Phosphate, and chlorophyll $a$, and a net primary production of around $0.155 \mathrm{gCm}^{-2} \cdot \mathrm{d}^{-1}$, which can be considered relatively, low (Tundisi \& MatsumuraTundisi, 1976, 1995; Rodríguez \& Matsumura-Tundisi, 2000). With regard to the zooplankton community, Rocha \& Matsumura-Tundisi (1984) calculated the mean annual production of Argyrodiaptomus furcatus (the dominant copepod in the reservoir) to be $1.43 \mathrm{mgCm}^{-3} \cdot \mathrm{d}^{-1}$ (assuming a carbon content of $38 \%$ of dry weight (Matsumura-Tundisi et al., 1989). This is considerably greater than that measured for the rotifers in the present study. Nevertheless, the reservoir is becoming more eutrophic with the increase of human activities in the vicinity and recent data of nutrients have shown higher concentration of nitrate $\left(797 \mu \mathrm{g} . \mathrm{L}^{-1}\right)$ and phosphate $\left(36.7 \mu \mathrm{g} . \mathrm{L}^{-1}\right)$ in the discharge of the main tributaries (data of July, 2001). For a greater understanding of production in this reservoir, it would be desirable to analyse the other zooplankton groups, such as the Cladocera and Protozoa, and other species of Copepoda. 


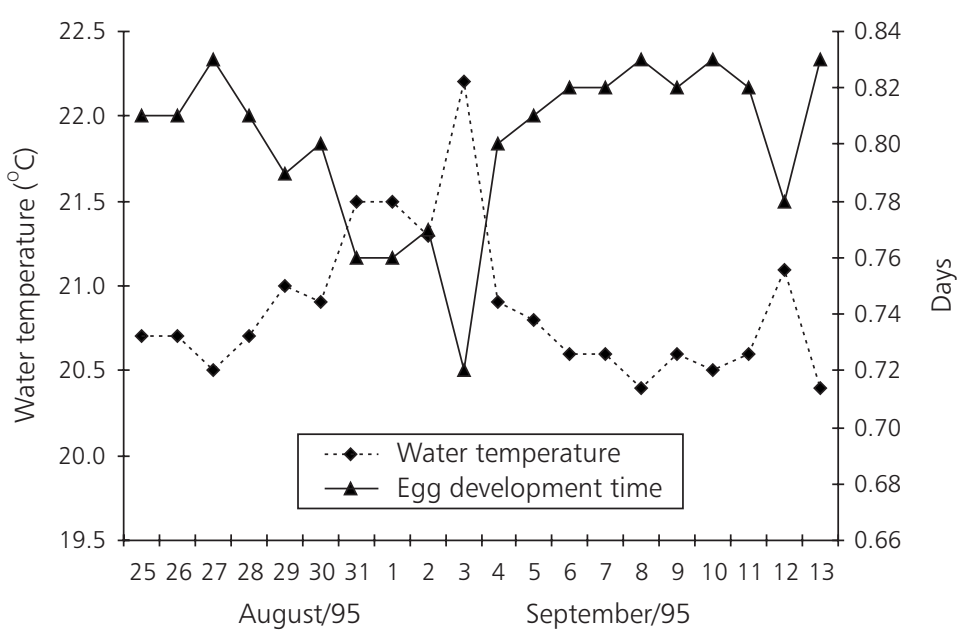

Fig. 2 - Daily variation in water temperature and egg development time during the period of August 25 to September 13, 1995, in the Lobo-Broa Reservoir.

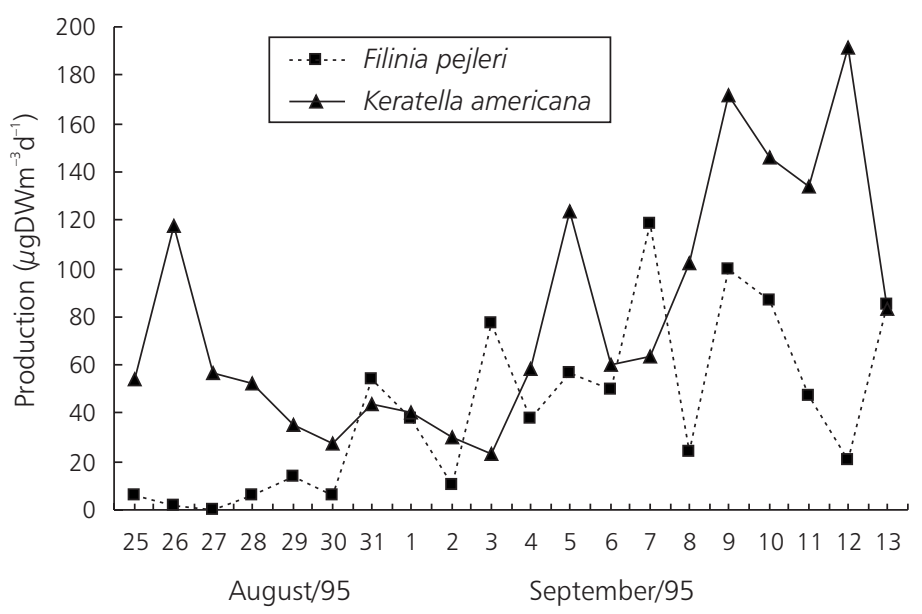

Fig. 3 - Daily variation in production $\left(\mu \mathrm{gDWm}^{-3} \mathrm{~d}^{-1}\right)$ of Filinia pejleri and Keratella americana, during the period of August 25 to September 13, 1995, in the Broa Reservoir.

Acknowledgments - The authors express their gratitude to CAPES (Coordenadoria de Aperfeiçoamento de Pessoal de Ensino Superior) and FAPESP (Fundação de Amparo à Pesquisa do Estado de São Paulo) for financial support - Processes: 91/0612-5; 98/05091-2).

\section{REFERENCES}

BOTTRELL, H. H., DUNCAN. A., GLIWICZ, Z. M., GRYGIEREK, E., HERZIG. A., HILLBRICHT-ILKOSKA, A., KUROSAWA, H., LARSON, P. \& WEGLENSKA, T., 1976, A review of some problems in zooplankton production studies. Norw. J. Zool., 24: 419-456.
DOWNING, J. A., 1984, Assessment of secondary production: the first step. In: J. A. DOWNING \& F. H. RIGLER (eds.), A manual on methods for the assessment of secondary productivity in fresh waters. IBP Handbook 17, Oxford, 2. ed., Cap.1, pp. 1-18.

DOWNING, J. A. \& RIGLER, F. H., 1984, A manual on methods for the assessment of secondary productivity in fresh waters. IBP Handbook 17, Oxford, 2. ed.

EDMONDSON, W. T., 1960, Reproductive rates of rotifers in natural populations. Mem. Ist. Ital. Idrobiol., 12: 21-77.

EDMONDSON, W. T. \& WINBERG, G. G., 1971, A manual on methods for the assessment of secondary productivity in fresh waters. IBP Handbook 17, Blackwell Scientific, Oxford, USA. 
EDMONDSON, W. T., 1974, Secondary production. Mitt. Internat. Verein. Limnol., 20: 229-272.

ELSTER, H. J., 1954, Uber die Populationsdynamik von Eudiaptomus gracilis Sars und Heterocope borealis Fischer im Bodensee-Obersee. Arch. Hydrobiol. Suppl., 20: $546-614$.

ELSTER, H. J., 1955, Ein Beitrag zur Produktionsbiologie des Zooplanktons. Int. Assoc. Theor. and Appl. Limnol., 12: 404-411.

ELSER, J. J., ELSER, M. M., MACKAY, N. A. \& CARPENTER, S. R., 1988, Zooplankton-mediated transitions between $\mathrm{N}$ - and P-limited algal growth. Limnology and Oceanography, 33(1): 1-14.

GALKOVSKAYA, G. A., 1965, Planktonnye kolovratki i ikh rol v produktivnosti vodoemov. Avtoref. Belorus. Gos. Univ. im. Lenina, Minsk, 19p.

INFANTE, A. G. de, 1988, The plankton of the continental waters. Washington, D. C. General Secretary of the Organization of the American States. This program Regional of Scientific and Technological Development. (biology series, monograph 33). (in Spanish).

MAKAREWICZ, J. C. \& LIKENS, G. E., 1979, Structure and function of the zooplankton community of Mirror Lake, New Hampshire. Ecological Monographs, 49(1): 109-127.

MATSUMURA-TUNDISI, T. \& TAVARES, L. H. S., 1986, Phytoplankton composition of Broa Reservoir and its utilization by Argyrodiaptomus furcatus (Copepoda Calanoida). In: Simpósio: Algas, Energia do Amanhã, São Paulo, 1986. Anais. Instituto Oceanografico, USP, São Paulo, pp. 183-188.

MATSUMURA-TUNDISI, T. \& TUNDISI, J. G., 1976 , Plankton studies in a lacustrine environment. I. Preliminary data on zooplankton ecology of Broa Reservoir. Oecologia, 25: 265-270.

MATSUMURA-TUNDISI, T., RIETZLER, A. C. \& TUNDISI, J. G., 1989, Biomass (dry weight and carbon content) of plankton Crustacea from Broa Reservoir (São Carlos, SP, Brazil) and its fluctuation across one year. Hydrobiologia, 179: 229-236.

MATSUMURA-TUNDISI, T. \& TUNDISI, J. G., 1986, Biomass and zooplankton community structure of three lakes of River Doce Valley (MG, Brazil). Fifth Japan-Brazil Symposium on Science and Technology, Tokyo, Japan.

NOGRADY, T., WALLACE, R. L. \& SNELL, T. W., 1993, Rotifera. Volume 1: Biology, ecology and systematics. Guides to the identification of the microinvertebrates of the continental waters of the world. SPB Academic Publishing, The Hague, 142p.

OKANO, Y. W., 1994, Analysis of the structure and population dynamics of the zooplankton community of an artificial reservoir (Monjolinho reservoir, São Carlos, SP). Doctoral Thesis, Federal University of São Carlos (in Portuguese), São Carlos, 128p.
PAULI, H. R., 1989, A new method to estimate individual dry weights of rotifers. Hydrobiologia, 186/187: 355361 .

ROCHA, O. \& MATSUMURA-TUNDISI, T., 1984, Biomass and production of Argyrodiaptomus furcatus, a tropical Calanoida in Broa reservoir, southern Brazil. Hydrobiologia, 113: 307-311.

RODRÍGUEZ, P. M. \& MATSUMURA-TUNDISI, T., 2000, Variations of density, species composition and dominance of rotifers at a shallow tropical reservoir (Broa Reservoir, SP, Brazil) in a short scale time. Rev. Brasil. Biol., 80(1): 1-9.

RUTTNER-KOLISKO, A., 1977, Suggestions for biomass calculation of plankton rotifers. Arch. Hydrobiol. Beihe. Ergebn. Limnol., 8: 71-76.

TAVARES, L. H. S. \& MATSUMURA-TUNDISI, T., 1984, Feeding in adult females of Argyrodiaptomus furcatus (Sars, 1901) Copepoda Calanoida of Lobo reservoir, São Carlos, Brazil. Hydrobiologia, 113: 15-23.

TAVARES, L. H. S., 1988, Use of plankton as feed for larvae and alevins of fish. São Carlos, 191p. Doctoral Thesis, Federal University of São Carlos. (in Portuguese)

TUNDISI, J. G., MATSUMURA-TUNDISI, T., STRIXINO, G., MARTINS, M., MATOS, M. A. \& SANTOS, E. P., 1972a, Ecological studies at Broa Reservoir. I. Progress Report. Federal University of São Carlos (report), 123p.

TUNDISI, J. G., MATSUMURA-TUNDISI, T., STRIXINO, G., MARTINS, M., MATOS, M. A. \& SANTOS, E. P., 1972b, Ecological studies at Broa Reservoir. II. Progress Report. Federal University of São Carlos (report), 165p.

TUNDISI, J. G. \& MATSUMURA-TUNDISI, T., 1976, Produção orgânica em ecossistemas aquáticos. Ciência e Cultura, 28(8): 864-887.

TUNDISI, J. G. \& MATSUMURA-TUNDISI, T., 1995, The Lobo-Broa ecosystem research. In: J. G. Tundisi, C. E. M. Bicudo \& T. Matsumura-Tundisi (eds.), Limnology in Brazil. Brazilian Academy of Sciences, Brazilian Limnological Society, pp. 219-244.

WINBERG, G. G., 1971, Methods for estimating the production of populations with continuous reproduction. In: G. G. Winberg, Methods for the estimation of production of aquatic animals. Translated from the Russian by A. Duncan. Royal Holloway College, University of London, London.

WINBERG, G. G., PATAlAS, K., WRIGHT, J. C., HILLBRICHT-ILKOWSKA, A., COOPER, W. E. \& MANN, K. H., 1971, Methods for calculating productivity. In: W. T. Edmondson \& G. G. Winberg, A manual on methods for the assessment of secondary productivity in fresh waters. IBP handbook 17. Oxford, USA, Blackwell Scientific, Cap. 7, pp. 296-316. 